\title{
Landscape fragmentation in Mediterranean Europe: A comparative approach
}

\author{
Andrea De Montis, Belén Martín, Emilio Ortega, Antonio Ledda, Vittorio Serra
}

A B S T R A C T

\begin{abstract}
Maintaining ecosystem continuity has become a central element in spatial planning policies. Several authors acknowledge the environmental, also known as landscape, fragmentation due to human action as one of the main causes which have negative effects on biodiversity. The phenomenon consists of the transformation of larger patches of habitat in smaller ones, or fragments, which tend to be more isolated than in the original condition. It is extremely evident in urban areas, including settlements and various transport and mobility infrastructures, whose main ecological effects include loss of habitat, increased mortality of plants, and isolation of animal and vegetal species. In this paper, we assess landscape fragmentation dynamics of six landscape units belonging to two European regions, i.e. Sardinia in Italy (from 2003 to 2008), and Andalusia in Spain (from 2005 to 2009). We developed on three indices: the Infrastructural Fragmentation Index (IFI), the Urban Fragmentation Index (UFI), and the Connectivity Index (CI). We found that coastal areas generally suffer from an higher pressure due to the demand of longer or faster transport infrastructures and new settlements and less fragmented areas tend to show the most relevant dynamics in a sort of convergent pattern. Even though landscape fragmentation and connectivity are intuitively complementary phenomena, in this paper we did not found any statistical evidence of this associative property.
\end{abstract}

\section{Introduction}

In the last decades, the expansion of human needs has caused a dramatically higher consumption of the planet's resources with tremendous impacts on land use change and a considerable loss of habitats and biodiversity (Foley et al., 2011; Foley et al., 2005). In addition to natural catastrophic events (Lindenmayer and Franklin, 2002), landscape fragmentation (LF) is a relevant process, where large habitat areas -called patches- become smaller and much more isolated (EEA, 2011; Jaeger, 2000). LF is related to an extensive "conversion of natural landscapes for human use" (Harrisson et al., 2012) and has negative effects on biodiversity (see, for example, Gibson et al., 2013). An important consequence of an increase in LF is a decrease in landscape connectivity (LC), i.e. an higher impedance to movement for mainly animal species, depending on the land cover pattern (Scolozzi and Geneletti, 2012). A relevant part of landscape metrics and analytics includes tools able to monitor LF and LC in space and time. The interpretation of these evaluations is key to planning adequate strategies to reduce and counteract landscape fragmentation. In spite of the relevance of the theme, scientific literature still presents some gaps and should be integrated with studies tackling the interplay between measures able to assess LF and LC.

In this paper, we aim at developing on and applying three measures, i.e. the Infrastructural Fragmentation Index (IFI), the Urban Fragmentation Index (UFI), and the Connectivity Index $(C I)$ to the assessment of the evolution of six landscape units (LUs) in Italy and Spain. We will address our argument trying to answer to the following research questions (RQs). Is it possible to assess landscape fragmentation and connectivity in space and time $\left(R_{1}\right)$ ? How are fragmentation and connectivity related $\left(R_{2}\right)$ ? Is it pos- 
sible to detect similar landscape fragmentation and connectivity processes in Mediterranean areas $\left(\mathrm{RQ}_{3}\right)$ ?

The issues of this paper will be presented as follows. In the next section, we present a state of the art summary on the studies concerning LF and LC and their assessment. In section three, we illustrate the evaluation method and the indicators included for the assessment of LF and LC. In the fourth section, we apply the method to the study of the dynamics of the landscapes of two similar Mediterranean countries. In the fifth section, we present the concluding remarks of this work.

\section{Landscape fragmentation and connectivity: a state of the art summary}

In some senses, LF and LC are complemental faces of a unique phenomenon affecting contemporary landscapes. We consider the natural environment fragmentation, i.e. LF, as the dynamic transformation of larger patches into smaller ones, or fragments, where the fragments tend to be more isolated than in the original condition (EEA, 2011; Jaeger, 2000). In this work, for patches we mean rural and peri-urban landscape areas occupied by habitats. Natural environment fragmentation is one of the main causes that has adverse effects on biodiversity (Battisti, 2004; Henle et al., 2004; Wilcove et al., 1986), such as the decline of population due to loss of functional connectivity (Harrisson et al., 2012) and richness of the species (Collinge, 1996). In addition, LF can exacerbate the effects of climate change, by inducing a shrinking of habitats' resilience, species population, and ecosystems' variety (Kettunen et al., 2007). LF derives from deforestation, agricultural land conversion, and urbanization of natural areas, and it is extremely evident in urban or intensively used areas, where it is due, for example, to infrastructure network (Igondova et al., 2016; EEA, 2011; Jongman, 2004; Saunders et al., 1991) and urban development (Battisti and Romano, 2007; Jongman, 2004; Serrano et al., 2002). Maintaining ecosystem continuity is becoming a central element in spatial planning policies (Romano and Tamburini, 2001). At the international level, some policies -including the Convention on Biological Diversity and the Ramsar Convention- have been developed in order to maintain ecological coherence and connectivity (Kettunen et al., 2007). Finally, though "the Landscape Convention does not explicitly address ecological coherence and connectivity, it provides an integrated framework that supports actions for such issues through landscape planning and management" (Kettunen et al., 2007). In this paper we study LC, in particular its functional component, which is understood as the degree to which the landscape facilitates or impedes movement (ecological flux of populations) among resource patches (Taylor et al., 1993).

As for the assessment methods adopted for measuring LF and LC, Butler et al. (2004) examine forest fragmentation in the Pacific Northwest (Oregon and Washington west of the crest of the Cascade Range) through a forest fragmentation index combining three metrics (percentage non-forest cover, percentage edge, and interspersion). Li et al. (2009) characterize forest spatial configurations in Alabama, the USA, using a historical record of 163 Landsat Thematic Mapper and select many indices (including core area index, edge density, largest polygon index, and mean polygon area) for assessing forest fragmentation. Li et al. (2010) quantify forest fragmentation patterns in China and the USA through a global land cover map and stress that Chinese forests show an higher fragmentation than those in the USA. Roads and railways have some impacts on ecological networks (Smith, 2004) and the main ecological effects produced by an infrastructure network include loss of habitat and biota, increased mortality of plants, death of animals killed by vehicular traffic and habitat fragmentation, which in turn triggers habitat loss (Jaarsma, 2004; Smith, 2004; Spellerberg,
1998 Smith, 2004; Spellerberg, 1998). Also the rural road network leads to LF, which depends on characteristics of the roads (Jaarsma and Willems, 2002). LF caused by roads and railways can be assessed using indices, such as the IFI, which is encountering the interest of some scholars (Bruschi et al., 2015; Fabietti et al., 2011; Guccione et al., 2008; Melis and Puddu, 2008; Battisti and Romano, 2007; Zanon et al., 2007; La Rovere et al., 2006; Biondi et al., 2003; Romano, 2002; Romano and Tamburini, 2001). With a closer attention for connectivity, landscape is commonly studied by means of indicators measuring different characteristics of a landscape's composition or spatial configuration (McGarigal and Marks, 1995; Forman et al., 2003). Changes in the spatial configuration of land uses and the presence of a new linear transport infrastructure have a major impact on the flows of matter and energy occurring in the ecosystems, and on the natural movement of individuals and on population dynamics (Trocmé et al., 2003), i.e., in LC. To study its effect on the environment, indicators are frequently used to measure the permissiveness of the territory to these movements (Scolozzi and Geneletti, 2012), although they have a certain degree of subjectivity due to the resistance values assigned. In recent years a number of researchers have developed LC indicators to model this process (Marulli and Mallarach, 2005; Saura and Pascual-Hortal, 2007; Mancebo Quintana et al., 2010; Gurrutxaga et al., 2011). In Table 1

\section{Methods}

The section is divided in two sub-sections. The first one concerns the indicators used for the assessment of LF and LC, while the second a tool able to inspect the level of correlation between those indices.

\subsection{Indicators of $L F$ and $L C$}

As for LF, we focus on fragmentation caused by mobility infrastructures and human settlements. Bruschi et al. (2015), Biondi et al. (2003), Romano (2002), and Romano and Tamburini (2001) selected the Infrastructural Fragmentation Index (IFI), which obeys to the following equation

$I F I^{*}=\frac{\left(\sum_{i=1}^{i=n} L_{i} \cdot O_{i}\right) \cdot N \cdot P}{A}$

where $\left(^{*}\right)$ stands for the reference year, $L_{i}$ for the length in meters of the road or railway trait with the exclusion of discontinuities (viaducts, bridges, tunnels), $O_{i}$ for the (dimensionless) occlusion coefficient, $A$ for the extension in squared meters of the landscape unit (LU) area; $P$ for the perimeter in meters of the $L U$, and $N$ for the number of patches. We consider patches larger than 0.20 ha to eliminate the distortion due to fictitious parts (Bruschi et al., 2015; Lega, 2004). $O_{i}$ varies according to the difficulty that the fauna has in crossing the transportation infrastructure (Bruschi et al., 2015): it is equal to 0.30 for municipal and local roads, to 0.50 for national and provincial roads, and to 1.00 for national four (or more) lane roads and railway. IFI is calculated at the scale of LU and increases with the extension of the surface area; thus it is ideal when comparing LUs with approximately the same extension (Bruschi et al., 2015; Romano and Tamburini, 2001). In this paper, we calculate $I^{*}{ }^{*}$ taking into account infrastructure discontinuities: Fig. 1 explains how we group the patches connected through bridges, tunnels or other similar links. Roads and railways layers have been imported in GIS environment as shapefile in polyline format and measured excluding discontinuity traits, namely tunnels and bridges. These spatial elements have been merged with LU's boundaries and converted into elements in polygon format. This has allowed us to obtain the landscape patches. The required value of occlusion coefficient has 
Table 1

Comparative scheme of LF and LC indicators.

\begin{tabular}{|c|c|c|c|c|c|}
\hline Indicators & Description & Formula & Variables & Pros & Cons \\
\hline $\begin{array}{l}\text { Infrastructural } \\
\text { Fragmentation Index } \\
\text { (IFI) (Bruschi et al., } \\
\text { 2015; La Rovere } \\
\text { et al., 2006; Romano } \\
\text { and Tamburini, } \\
\text { 2001) }\end{array}$ & $\begin{array}{l}\text { It is useful for } \\
\text { measuring landscape } \\
\text { fragmentation caused } \\
\text { by transport and } \\
\text { mobility } \\
\text { infrastructures. }\end{array}$ & $\begin{array}{l}I F I=\backslash i=1 \\
L_{i} \text { : length of the } i \text {-th road or } \\
\text { railway infrastructure; } \\
O_{i}: \text { dimensionless occlusion } \\
\text { coefficient of the } i \text {-th } \\
\text { infrastructure; } \\
N \text { : number of patches in which } \\
\text { the territorial unit is } \\
\text { fragmented by the } \\
\text { infrastructures; } \\
\text { Pt: territorial unit perimeter; } \\
\text { At: territorial unit area. }\end{array}$ & $\begin{array}{l}\text { Type of infrastructure. } \\
\text { Length of road and railway } \\
\text { traits. } \\
\text { Extension and perimeter of } \\
\text { territorial unit. } \\
\text { Number of patches. } \\
\text { Occlusion coefficient. }\end{array}$ & $\begin{array}{l}\text { It is adopted and verified in } \\
\text { other scientific studies. } \\
\text { It provides a quantitative } \\
\text { measure of landscape } \\
\text { fragmentation. } \\
\text { It can be used in comparative } \\
\text { approaches. }\end{array}$ & $\begin{array}{l}\text { Finer measure requires the use } \\
\text { of data on traffic density by } \\
\text { hour, day, month, and season. } \\
\text { IFI increases with the } \\
\text { extension of the LU surface } \\
\text { area, so should be calculated } \\
\text { for areas of approximately the } \\
\text { same extension. }\end{array}$ \\
\hline $\begin{array}{l}\text { Infrastructural } \\
\text { Fragmentation Index } \\
\text { (IFI) (La Rovere et al., } \\
\text { 2006) }\end{array}$ & & $\begin{array}{l}I F I=\frac{1}{S t} \\
L_{i}: \text { length of the } i \text {-th road or } \\
\text { railway infrastructure; } \\
O_{i}: \text { occlusion coefficient of the } \\
i \text {-th infrastructure; } \\
\text { At: territorial unit area. }\end{array}$ & $\begin{array}{l}\text { Type of infrastructure. } \\
\text { Length of road and railway } \\
\text { traits. } \\
\text { Extension of territorial unit. } \\
\text { Occlusion coefficient. }\end{array}$ & & \\
\hline $\begin{array}{l}\text { Linear Infrastructural } \\
\text { Fragmentation Index } \\
\text { (Neri et al., 2010) }\end{array}$ & & $\begin{array}{l}I F I=\frac{\left(\Sigma\left(L_{i} \cdot O_{i}\right)\right)}{S t} \\
L i: \text { length of the } i \text {-th road or } \\
\text { railway infrastructure; } \\
\text { li: width of the } i \text {-th road or } \\
\text { railway infrastructure; } \\
A u \text { : territorial area referred to a } \\
\text { cell of } 1 \mathrm{~km}^{2} .\end{array}$ & $\begin{array}{l}\text { Type of infrastructure. } \\
\text { Length and width of road and } \\
\text { railway traits. }\end{array}$ & $\begin{array}{l}\text { It does not increase with the } \\
\text { extension of the LU surface } \\
\text { area. } \\
\text { It allows to find the best } \\
\text { allocation for new projects of } \\
\text { road infrastructures. } \\
\text { It is adopted and verified in } \\
\text { other scientific studies. } \\
\text { It provides a quantitative } \\
\text { measure of landscape } \\
\text { fragmentation. } \\
\text { It can be used in comparative } \\
\text { approaches. }\end{array}$ & $\begin{array}{l}\text { Finer measure requires the use } \\
\text { of data on traffic density by } \\
\text { hour, day, month, and season. }\end{array}$ \\
\hline $\begin{array}{l}\text { UFI (Battisti et al., } \\
\text { 2013; Romano and } \\
\text { Zullo, 2013; Battisti } \\
\text { and Romano, 2007) }\end{array}$ & $\begin{array}{l}\text { It provides a quantitative } \\
\text { measure of landscape } \\
\text { fragmentation caused by } \\
\text { settlements. }\end{array}$ & $\begin{array}{l}U F I=\frac{\overline{i=1}}{A} \cdot \frac{\sqrt{i=1}}{\sqrt[2]{\sqrt{\sum_{i=1}^{i=n} s_{i}}}} \\
S_{i}: \text { extension of the } i \text {-th urban } \\
\text { area; } \\
p_{i} \text { : perimeter of the } i \text {-th urban } \\
\text { area. }\end{array}$ & $\begin{array}{l}\text { Extension and perimeter of } \\
\text { settlements. } \\
\text { Extension of LU. }\end{array}$ & $\begin{array}{l}\text { It provides a quantitative } \\
\text { measure of landscape } \\
\text { fragmentation. } \\
\text { It is adopted and verified in } \\
\text { other scientific studies. } \\
\text { It can be used in comparative } \\
\text { approaches. }\end{array}$ & $\begin{array}{l}\text { It does not take into account } \\
\text { the obstruction, which varies } \\
\text { depending on settlements' } \\
\text { typology. }\end{array}$ \\
\hline
\end{tabular}




\begin{tabular}{|c|c|c|c|c|c|}
\hline Indicators & Description & Formula & Variables & Pros & Cons \\
\hline $\begin{array}{l}\text { UFI (Astiaso Garcia } \\
\text { et al., 2013) }\end{array}$ & & $\begin{array}{l}\text { UFI }=\frac{I_{i=1}}{\text { At }} \\
\text { Lmax } i \text { : maximum length of the } \\
i \text {-th urban barrier inside the } \\
\text { territorial unit; } \\
S_{i}: \text { area of the } i \text {-th urban } \\
\text { barrier; } \\
O_{i}: \text { obstruction coefficient of } \\
\text { the } i \text {-th urban barrier; } \\
\text { At: territorial unit area. }\end{array}$ & $\begin{array}{l}\text { Extension of settlements. } \\
\text { Length of urban barrier. } \\
\text { Obstruction coefficient. } \\
\text { Extension of LU. }\end{array}$ & $\begin{array}{l}\text { It provides a quantitative } \\
\text { measure of landscape } \\
\text { fragmentation. } \\
\text { It is adopted and verified in } \\
\text { other scientific studies. } \\
\text { It can be used in comparative } \\
\text { approaches. } \\
\text { It takes into account the } \\
\text { obstruction which varies } \\
\text { depending on settlements' } \\
\text { typology. }\end{array}$ & \\
\hline Ufim (Neri et al., 2010) & & $\begin{array}{l}\text { Ufim }=\frac{\left(\sum_{N}^{A c i}\right)}{\text { Api: extension of the } i-t h \text { Asp }_{\text {Arban }}} \\
\text { area; } \\
\text { Aci: extension of the ideal } \\
\text { circumference; } \\
\text { Asp: territorial unit area } \\
\left(1 \mathrm{~km}^{2}\right) ; \\
\mathrm{N}: \text { number of patches in which } \\
\text { the territorial unit is } \\
\text { fragmented. }\end{array}$ & $\begin{array}{l}\text { Extension of settlements. } \\
\text { Extension of the ideal } \\
\text { circumference. } \\
\text { Number of patches. }\end{array}$ & $\begin{array}{l}\text { It does not increase with the } \\
\text { extension of the LU surface } \\
\text { area. } \\
\text { It is adopted and verified in } \\
\text { other scientific studies. } \\
\text { It can be used in comparative } \\
\text { approaches. }\end{array}$ & \\
\hline $\begin{array}{l}\text { Connectivity Index } \\
\text { (Mancebo Quintana } \\
\text { et al., 2010) }\end{array}$ & $\begin{array}{l}\text { It estimates the connectivity } \\
\text { between all the patches taking } \\
\text { into account the spatial } \\
\text { configuration of artificial and } \\
\text { natural land uses, and } \\
\text { infrastructure barriers, in large } \\
\text { territories. }\end{array}$ & $\begin{array}{l}C I_{i}^{*}=\frac{j=1}{2 \pi d e_{\max }} \\
d e_{i, j}: \text { effective distance; } \\
A_{j}: \text { area of each destination; } \\
2 \pi d e_{\max }: \text { the maximum } \\
\text { possible value of the } \\
\text { numerator. }\end{array}$ & $\begin{array}{l}\text { Type of barrier. } \\
\text { Effective distance. } \\
\text { Available area. } \\
\text { Distribution of land uses. } \\
\text { Habitat type. }\end{array}$ & $\begin{array}{l}\text { It can be used for comparing } \\
\text { different geographical areas or } \\
\text { different time periods in the } \\
\text { same area. It is useful to } \\
\text { compare different alternatives } \\
\text { when assessing the impacts of } \\
\text { regional and urban plans. }\end{array}$ & $\begin{array}{l}\text { It is not sensitive to the } \\
\text { disappearance of single } \\
\text { stepping-stone patches. }\end{array}$ \\
\hline $\begin{array}{l}\text { Ecological Connectivity } \\
\text { Index } \\
\text { (Marulli and } \\
\text { Mallarach, 2005) }\end{array}$ & $\begin{array}{l}\text { It diagnoses the connectivity of } \\
\text { terrestrial landscape } \\
\text { ecosystems, on the basis of a } \\
\text { previously defined set of } \\
\text { ecological functional areas, and } \\
\text { a computational cost-distance } \\
\text { model which includes the } \\
\text { barrier effect. }\end{array}$ & $\begin{array}{l}E C I=10-9 \frac{\ln \left(1+\left(x_{i}-x_{\min }\right)\right)}{\ln \left(1+\left(x_{\max }-x_{\min }\right)\right)^{3}} \\
x_{i}: \text { adapted cost-distance value } \\
\text { in a pixel; } \\
x_{\max }, x_{\min }: \text { maximum and } \\
\text { minimum adapted } \\
\text { cost-distance values on a given } \\
\text { area. }\end{array}$ & $\begin{array}{l}\text { Type of barrier. } \\
\text { Effective distance. } \\
\text { Adjacent land use. } \\
\text { Vegetation type. }\end{array}$ & $\begin{array}{l}\text { It is useful to compare different } \\
\text { alternatives when assessing } \\
\text { the impacts of regional and } \\
\text { urban plans. }\end{array}$ & $\begin{array}{l}\text { In cannot be used for } \\
\text { comparing different } \\
\text { geographical areas or different } \\
\text { time periods in the same area. } \\
\text { It is not sensitive to the } \\
\text { disappearance of single } \\
\text { stepping-stone patches. }\end{array}$ \\
\hline $\begin{array}{l}\text { Probability of } \\
\text { Connectivity } \\
\text { (Saura and } \\
\text { Pascual-Hortal, } \\
\text { 2007; Gurrutxaga } \\
\text { et al., 2011) }\end{array}$ & $\begin{array}{l}\text { It measures connectivity based } \\
\text { on the habitat availability } \\
\text { concept, dispersal probabilities } \\
\text { between habitat patches and } \\
\text { graph structures. }\end{array}$ & $\begin{array}{l}P C=\frac{\sum_{\mathrm{i}=1}^{\mathrm{n}} \sum_{\mathrm{j}=1}^{\mathrm{n}} \mathrm{a}_{\mathrm{i}} \mathrm{a}_{\mathrm{j}} \mathrm{p}_{\mathrm{ij}}^{*}}{\mathrm{~A}_{\mathrm{L}}^{2}} \\
a_{i} \text { and } a_{j}: \text { areas of the habitat } \\
\text { patches } i \text { and } j ; \\
A_{L}: \text { the total landscape area; } \\
p_{i j}^{*}: \text { maximum product } \\
\text { probability of all possible paths } \\
\text { between patches } i \text { and } j .\end{array}$ & $\begin{array}{l}\text { Available area. } \\
\text { Dispersal probabilities. } \\
\text { Graph structures. }\end{array}$ & $\begin{array}{l}\text { It can be used for comparing } \\
\text { different geographical areas or } \\
\text { different time periods in the } \\
\text { same area. } \\
\text { Is it able to detect the higher } \\
\text { importance of key } \\
\text { stepping-stone patches. It is } \\
\text { useful to compare different } \\
\text { alternatives when assessing } \\
\text { the impacts of regional and } \\
\text { urban plans. }\end{array}$ & $\begin{array}{l}\text { It cannot measure connectivity } \\
\text { in an individual patch. The } \\
\text { entire landscape is quantified. } \\
\text { It does not distinguish the type } \\
\text { of barrier. }\end{array}$ \\
\hline
\end{tabular}




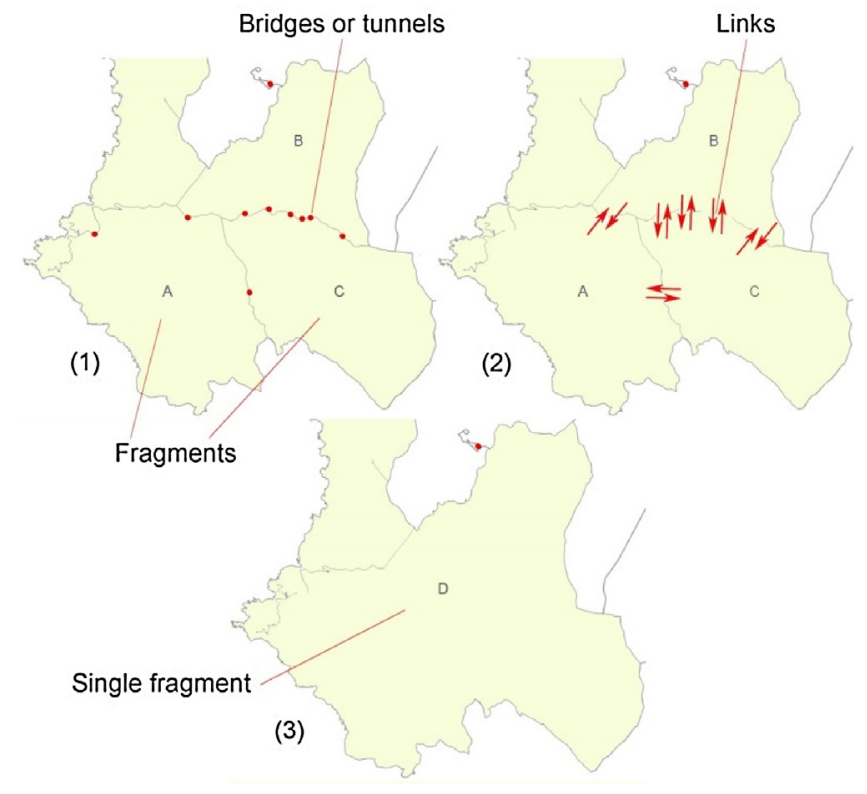

Fig. 1. Incorporating transport infrastructure discontinuities in the identification of fragments. (1) Initial scenario with three landscape fragments (A, B, C) limited by the road and railway network (in gray) showing discontinuities such as bridges and tunnels (in red); (2) identification of discontinuities as opportunity of connection between the fragments; (3) final scenario with a single fragment (D) obtained through the coalition of the three original fragments. (For interpretation of the references to colour in this figure legend, the reader is referred to the web version of this article.)

been attributed to each transport infrastructure's type. This has enabled us to a straightforward management of the calculations connected to IFI's equation.

Urbanization induces effects on ecological networks (De Montis et al., 2016) and causes fragmentation processes and soil consumption, which produce qualitative and quantitative effects on habitat, flora, and fauna (Astiaso Garcia et al., 2013). LF due to urban areas can be assessed through the UFI (Astiaso Garcia et al., 2013; Battisti and Romano, 2007; Biondi et al., 2003). According to Romano and Zullo (2013) and Battisti and Romano (2007), the UFI obeys to the following equation

$U F^{*}=\frac{\sum_{i=1}^{i=n} S_{i}}{A} \cdot \frac{\sum_{i=1}^{i=n} p_{i}}{2 \sqrt{\pi \sum_{i=1}^{i=n} S_{i}}}$

where $S_{i}$ stands for the extension in squared meters of the $i$-th urban area, $p_{i}$ for the perimeter in meters of the i-th urban area. The first term of Eq. (2) quantifies the incidence of urbanized areas on the LU surface; the second term is the ratio between the perimeter of the urban area and the circumference of the equivalent circle (Romano and Zullo, 2013). UFI is again calculated at the scale of LU and ranges between zero (for absence of urban areas) and the value of the second term of Eq. (2) (Battisti et al., 2013). We perform calculations connected to $U F I^{* \prime}$ s equation by taking into account the following land-use classes: continuous urban fabric, discontinuous urban fabric, and industrial or commercial areas. We processed information in a GIS environment with the following main routines: union of land-use classes in a single layer, dissolution of this layer to delete the internal perimeter of the original urban areas, and exportation of the attribute table to an excel format spreadsheet.

In the next section, we illustrate the application of the two indices to the measurement of LF change from 2003 to 2008 for three LUs in Sardinia, Italy, and from 2005 to 2009 for three LUs in Spain.

We are interested in the dynamics of landscape form the year $s$ to $k$, thus to the variation of $I F I^{*}$ and $U F I^{*}$ according to the following equations:

$$
\begin{aligned}
& \Delta I F I^{*}{ }_{k-s}(\%)=\frac{I F I_{k}-I F I_{s}}{I F I_{s}} \cdot 100 \\
& \Delta U F I^{*}{ }_{k-s}(\%)=\frac{U F I_{k}-U F I_{s}}{U F I_{s}} \cdot 100
\end{aligned}
$$

The LC is analysed using the connectivity indicator $\mathrm{CI}_{\mathrm{i}}{ }^{*}$ (Mancebo Quintana et al., 2010). Its calculation is based in GIS and it has been demonstrated to be useful in landscape and infrastructure planning in several studies (Mancebo Quintana et al., 2010; Martín et al., 2016; Ortega et al., 2016).

It assigns a value for the scenario* to each pixel $i$ in the study zone, and measures the area corresponding to the same type of natural habitat as that of the cell in question, divided by the effective distance between the pixel and the analogous habitat. The calculation is done in an area of influence of each pixel, and the value obtained is divided by the maximum value that could be achieved, so the range of values for $C I$ is between 0 (minimum connectivity) and 1 (maximum connectivity). The following equation holds:

$C I_{i}^{*}=\frac{\sum_{j=1}^{n} \frac{A_{j}}{2 \pi d e_{i, j}}}{2 \pi d e_{\max }}$

where $C_{\mathrm{i}}{ }^{*}$ is the value of the connectivity index for starting pixel $i$ in the scenario corresponding to the year *; $d e_{i, j}$ is the effective distance between starting point $i$ and destination $j ; A_{j}$ is the area of each one of the $n$ destinations $j$ that belong to the same class of natural area as starting point $i$ and $2 \pi d e_{\max }$ is the maximum possible value of the numerator. $\mathrm{CI}_{\mathrm{i}}{ }^{*}$ is a function of the effective distance. This is the minimum distance between two points separated by a resistance matrix that models the difficulty encountered by organisms in moving around the territory. The distance between two points that belong to the same type of natural habitat is penalised if there are patches between them in the matrix that can be considered as obstacles (such as infrastructure, artificial or natural areas that correspond to a different type or category). The effective difference is calculated using Dijkstra's algorithm (1959), and the resistance matrix is obtained using the values established by Mancebo Quintana et al. (2010). Changes in the spatial configuration of land uses and new infrastructure barriers are reflected in the values of $C I$. The GIS steps used to perform the indicator were programmed in Arc Macro Language for ArcInfo workstation. They are summarized as follows (for a more detailed description, see Mancebo Quintana et al. (2010)): (i) first, the origins and destinations are established using reclass functions. The origins are the pixels considered as natural areas in the study zone and classified into categories with common characteristics. The destinations are, for each origin, the pixels belonging to the same type according to the categories established. This information must be compiled on a layer in raster format with a cell size adequate for the scale of the work. (ii) In a second step, maps or resistance matrixes are created for each type of natural land use. Each cell in the resistance map is attributed a value that is a simplification of the opposition offered by the territory to the movement of the organisms between pixels corresponding to the same type as the origin pixel. These values are assigned taking into account the type of natural habitat, the types of linear infrastructures present in the study zone, and the existence of artificial land uses (industrial and urban areas). (iii) Finally, the indicator is calculated using ArcInfo costdistance function for each pixel $i$ in the territory using Eq. (5). This process is repeated in each 
of the scenarios considered in the case study, making it possible to measure the variation in LC between scenarios (at the years $k$ and $s$ ) as a percentage with regard to the initial situation according to the following equation:

$\Delta C I_{i, k-s}^{*}(\%)=\frac{C I_{i}^{k}-C I_{i}^{s}}{C I_{i}^{s}} \cdot 100$

The information, in a format compatible with GIS, required to calculate this indicator is - for each year- a network of linear infrastructures in the study zone that distinguishes between the different typologies, and a layer that distinguishes the different types of natural and artificial zones: in our case study, we used land-use maps.

\subsection{Analysis of the relationship between indicators}

To study the relationships between measures, three ( 2 by 2 ) contingency tables where constructed, as many as the couples of the three indexes $\left(I F I^{*}, U F I^{*}\right.$ and $\left.C I^{*}\right)$, and the Fischer's exact test was performed. In particular, we considered the average yearly variation (AYV) of each index, in order to prevent the bias related to the different time periods. Connectivity index values have been averaged over the different land-uses selected.

The average yearly variation was considered low, when its value is smaller than the mean value of the yearly variations in the LU. High variation was considered in the rest of the cases. Significant relationships were sought by using the Fisher's exact test, which is adequate when expected frequencies are less than or equal to 5 (the null hypothesis reflects independence between variations per year of the indicators; $\alpha=0.05$ ).

\section{A case study in Sardinia (Italy) and Andalusia (Spain)}

This section is divided into four sub-sections concerning the selection of the LUs and the dataset processed, the presentation of the results, the analysis of the association between the indicators calculated, and the discussion of the output with possible interpretations.

\subsection{LUs selection and datasets}

We selected six LUs belonging to the two regions of Sardinia, Italy and Andalusia, Spain, that have a Mediterranean landscape character. As described in Table 2 and Fig. 2, the Italian LUs are defined in the Regional Landscape Plan (RLP) of Sardinia (RAS, 2006) and the Spanish ones by the Regional Government of Andalusia (Junta de Andalucía, 2003). The three Andalusian LUs are a Mediterranean mountain range (Sierra Bermeja); a coastal area (Litoral Occidental Onubense) and a landscape constituted mainly by olive groves (Las Lomas). The Sardinian LUs consist of a coastal area (Golfo dell'Asinara) interested by relevant residential and productive industrial and agricultural settlements, and two much less developed interior zones characterized by the most relevant mountains of the island (Gennargentu and Mandrolisai) and upland basaltic plains (Regione delle giare basaltiche).

LUs' selection criteria are crucial with respect to $R_{2}$, i.e. the investigation of cognate landscape processes, as they are based on two main similarities. The first one attains to the common location in the same macro-geographical area at the borders of southern Europe. The second one consists in analogue institutional and processual settings.

As for the first similarity, the Mediterranean basin ranks among the richest areas on earth in terms of biodiversity (Blondel et al., 2010). Having been occupied by humans for around eight thousand years, its landscapes have co-evolved with traditional land uses for centuries. It is a densely populated area and it is also visited by millions of tourists every year, which makes it a biodiversity hotspot under threat (Cuttelod et al., 2008).

As for the second one, Italy and Spain show similar institutional settings, as they are regionalized unitary states, where the competence over landscape planning and management is devolved to the regions. In these southern European nations, the ELC has been signed, ratified, and operationalized with a strong commitment by local peripheral bodies (De Montis, 2014). In 2004, Italy has approved the legislative decree (Lgs. D.) n. 42 (Italian regulation, 2004), which translates the principles of the ELC into the local juridical system. At the moment, roughly a half of the Italian regions have approved a landscape plan complying with the Lgs. D. 42/2004 (De Montis, 2016). Sardinia is the second largest Mediterranean island and was the first Italian region to issue the RLP (RAS, 2006), in accordance to the Lgs. D. 42/2004. The RLP is actually in force on twenty-seven LUs located in the coastal buffer and promotes the protection and valorisation of local landscapes. The design of LUs is based on the combination of three aspects: environment, history and culture, and settlements. Each LU is described in specific fact-sheets, where the analysis of the three aspects leads to the formulation of planning directions. The RLP is key to the entire planning systems as municipal master plans are being redesigned in accordance.

Andalusia, located in the south of Spain, has a long tradition in landscape planning. The region was one of the leaders of the Mediterranean landscape Charter of 1992 which constituted one of the main background of the European landscape convention (ELC) (Council of Europe, 2000). The ELC came into force in 2008 in Spain. Since then, the Regional Government expressly includes the landscape in the legal system, in accordance with the ELC. The Land Use Plan of Andalusia (Junta de Andalucía, 2006) includes a coordinated Landscape Programme, whose main goal is the integration of impact analyses in the definition of all policies affecting directly or indirectly the landscape. The Landscape Map of Andalusia was developed according to three levels: five landscape categories, nineteen landscape areas, and eighty-one LUs. LUs correspond to regional landscape identities, defined on the basis of observation criteria -i.e. homogeneity of colors, textures, and structures- and physical-cultural, socio-cultural, and land-use variables.

We based the calculations for obtaining the three indices on processing the following data sets. With respect to Sardinia, the regional land cover map (RLCM) corresponding to the years 2003 and 2008 provided information on transportation infrastructures and urban areas. The reference scale of the RLCM is $1: 25,000$, while the minimum mapped unit spans 0.50 ha within the urban area and 0.75 ha in the extra urban areas (RAS, 2016a). The regional administration has checked and integrated this information through photo interpretation of Ikonos images issued in 2005-2006, Landsat images issued in 2003, and Aster images issued in 2004, and a 4000 point survey on the Regional Technical Map 1:10,000. We mainly use data available on-line in the official website of the Autonomous Region of Sardinia (RAS, 2016b) in shapefile format and based on Corine Land Cover classification concerning: LUs, road and railway network (including bridges, viaducts, and tunnels), urban settlements or other populated areas, industrial and commercial areas. Orthophotos are available on-line through the Web Map Service of the Region. As for Andalusia, land uses were obtained from the Spanish Land Occupation Information System (SIOSE) at a scale of $1: 10,000$ provided by the Regional Government of Andalusia for the years 2005 and 2009 (Junta de Andalucia, 2016). SIOSE uses the same reference image as Corine Land Cover, which makes both databases compatible. Road and rail infrastructure data were obtained from the bureau of spatial data of Andalucia for the mentioned years (IDEA, 2016). The study areas consist in the domains within the borders of the six LUs. But we have calculated 
Table 2

The landscape units selected in this study.

\begin{tabular}{|c|c|c|c|c|c|}
\hline State & Region & Code & Local linguistic denomination & Area $\left(\mathrm{km}^{2}\right)$ & Perimeter $(\mathrm{km})$ \\
\hline \multirow[t]{3}{*}{ Italy } & Sardinia & IS1 & Golfo dell'Asinara & 807 & 383 \\
\hline & & IS2 & Gennargentu and Mandrolisai & 1010 & 233 \\
\hline & & IS3 & Regione delle giare basaltiche & 926 & 215 \\
\hline \multirow[t]{3}{*}{ Spain } & Andalusia & SA1 & Las Lomas & 1027 & 339 \\
\hline & & SA2 & Litoral Occidental Onubense & 864 & 352 \\
\hline & & SA3 & Sierra Bermeja & 1191 & 389 \\
\hline
\end{tabular}
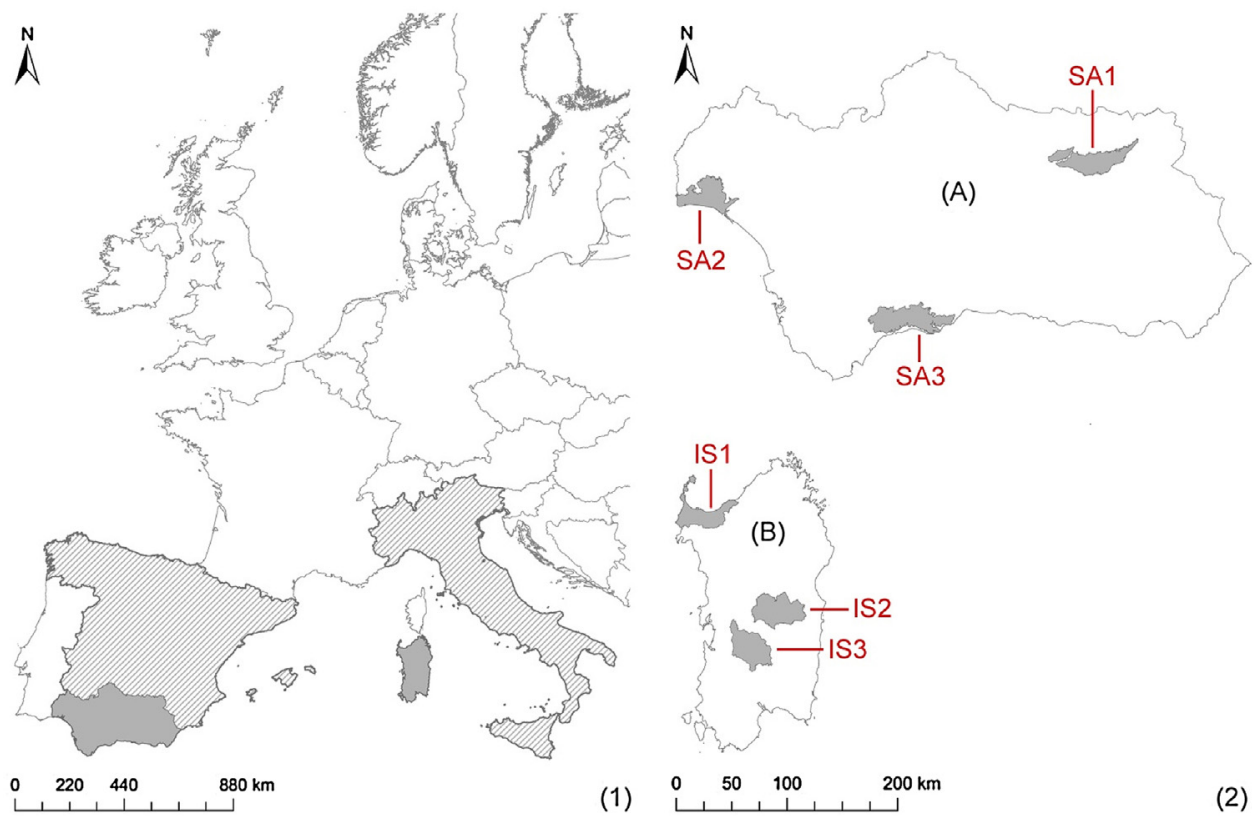

(1)

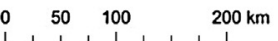

(2)

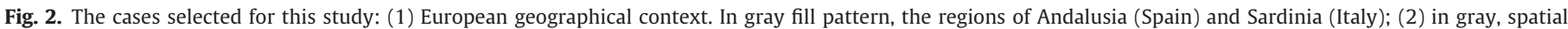
location of each LU in Andalusia (A) and Sardinia (B).

Table 3

Sardinian LUs: IFland UFI dynamics from 2003 to 2008.

\begin{tabular}{|c|c|c|c|c|c|c|}
\hline \multirow[t]{2}{*}{ LUs } & \multicolumn{3}{|l|}{ IFI } & \multicolumn{3}{|l|}{ UFI } \\
\hline & 2003 & 2008 & $\Delta$ & 2003 & 2008 & $\Delta$ \\
\hline Golfo dell'Asinara & 19655 & 21408 & $8.92 \%$ & 1.06 & 1.32 & $24.52 \%$ \\
\hline Regione delle giare basaltiche & 8356 & 8439 & $1.00 \%$ & 0.26 & 0.28 & $7.69 \%$ \\
\hline Gennargentu and Mandrolisai & 186 & 232 & $24.63 \%$ & 0.07 & 0.07 & - \\
\hline
\end{tabular}

Table 4

Andalusian LUs. IFI and UFI dynamics from 2005 to 2009.

\begin{tabular}{|c|c|c|c|c|c|c|}
\hline \multirow[t]{2}{*}{ LUs } & \multicolumn{3}{|l|}{ IFI } & \multicolumn{3}{|l|}{ UFI } \\
\hline & 2005 & 2009 & $\Delta$ & 2005 & 2009 & $\Delta$ \\
\hline Las Lomas & 7419 & 7760 & $4.59 \%$ & 0.34 & 0.37 & $8.82 \%$ \\
\hline Litoral Occidental Onubense & 27354 & 29839 & $9.09 \%$ & 0.91 & 0.91 & - \\
\hline Sierra Bermeja & 17797 & 18819 & $5.74 \%$ & 0.91 & 1.05 & $8.82 \%$ \\
\hline
\end{tabular}

the $\mathrm{CI}$ including a buffer of $50 \mathrm{~km}$, to avoid distortions connected to border errors (Mancebo Quintana et al., 2010).

\subsection{Results}

In Tables 3 and 4, we present the values obtained for IFI* and UFI* for Sardinian and Andalusian LUs. Litoral Occidental Onubense shows always the highest absolute value of $I F I^{*}$ and GennargentuMandrolisai the least one. Gennargentu-Mandrolisai shows the highest $\Delta I F I^{*}$ (24.63\%), while the Regione delle giare basaltiche the least (1.00\%). Golfo dell'Asinara shows always the highest absolute value of UFI (1.06 in 2003 and 1.32 in 2008), while GennargentuMandrolisai the least one (0.07). In addition, Golfo dell'Asinara shows the highest $\Delta U F{ }^{*}$ (24.52\%). Litoral Occidental Onubense is the most fragmented since it shows always the highest values of $I F I$ and $U F I^{*}$ in Spanish LUs. As for the dynamics, $\triangle U F I^{*}$ is negligible for Litoral Occidental Onubense and equal to $8.82 \%$ for both the other Spanish LUs. As for LC, Tables 5 and 6 provide the reader with the values of average and differential $\mathrm{CI}^{*}$, while Figs. 3 and 4 convey spatial representations by main natural land uses. Fig. 3 shows LC changes in the Sardinian LUs. Golfo dell'Asinara (Fig. 3, top) presents loss of LC distributed in its whole area, reaching higher values $(>20 \%)$ in the most populated zones. Nevertheless, Table 5 shows that the LC loss of average $\mathrm{CI}^{*}$ occurs in the land use shrub and/or herbaceous vegetation association $\left(\Delta C I^{*}=-4.33 \%\right)$, whilst in forests and open spaces with little or no vegetation, the $C I$ average value increases $\left(\Delta C I^{*}=32.34 \%\right.$ and $\Delta C I^{*}=1.12 \%$ ). The geographic distribution of LC losses in Giare Basaltiche and Genargentu-Mandrolisai are in Fig. 3 (medium and bottom). It is to highlight the big number of pixels where there is a LC gain. Changes in the configuration of landscape matrix between 2003 and 2008 cause these $\mathrm{CI}^{*}$ improvements despite the barrier effect of new infrastructure and artificial zones. If average values of $\mathrm{CI}^{*}$ in the main natural land uses are compared (Table 5), forests lose LC in both LUs $(-4.60 \%$ and $-2.41 \%)$ and there is a big gain of average $\mathrm{CI}^{*}$ in open spaces with little or no vegetation in GennargentuMandrolisai (41.21\%).

Pixels with gain of LC between the scenarios are not as frequent in Spanish LUs as they are in Sardinia (Figs. 3 and 4). The highest loss of LC is located in red zones in Sierra Bermeja and Litoral Occidental 
Table 5

Sardinian LUs. Analysis of Average CI changes per main natural land uses from 2003 to 2008.

\begin{tabular}{|c|c|c|c|c|c|c|c|}
\hline \multirow[t]{2}{*}{ LUs } & \multirow[b]{2}{*}{2003} & \multicolumn{3}{|l|}{$\operatorname{Avg} C I$} & \multicolumn{3}{|c|}{ Area (ha) } \\
\hline & & 2008 & $\Delta \mathrm{AvgCI}$ & 2003 & 2008 & $\Delta$ Area & \\
\hline \multirow[t]{4}{*}{ Golfo dell'Asinara } & Land uses & & & & & & \\
\hline & Forests & 0.0200 & 0.0265 & $32.34 \%$ & 3650 & 5500 & $50.7 \%$ \\
\hline & Shrub and/or herbaceous vegetation association & 0.0264 & 0.0253 & $-4.33 \%$ & 18725 & 15425 & $-17.6 \%$ \\
\hline & Open spaces with little or no vegetation & 0.0202 & 0.0205 & $1.12 \%$ & 2625 & 2475 & $-5.7 \%$ \\
\hline \multirow{4}{*}{ Regione delle giare basaltiche } & Land uses & & & & & & \\
\hline & Forests & 0.0451 & 0.0431 & $-4.60 \%$ & 8884 & 9150 & $3.0 \%$ \\
\hline & Shrub and/or herbaceous vegetation association & 0.0341 & 0.0336 & $-1.37 \%$ & 16994 & 16981 & $-0.1 \%$ \\
\hline & Open spaces with little or no vegetation & 0.0403 & 0.0329 & $-18.45 \%$ & 74 & 47 & $-36.5 \%$ \\
\hline \multirow[t]{4}{*}{ Gennargentu and Mandrolisai } & Land uses & & & & & & \\
\hline & Forests & 0.1056 & 0.1030 & $-2.41 \%$ & 41712 & 41674 & $-0.1 \%$ \\
\hline & Shrub and/or herbaceous vegetation association & 0.0587 & 0.0614 & $4.57 \%$ & 39931 & 44447 & $11.3 \%$ \\
\hline & Open spaces with little or no vegetation & 0.0416 & 0.0588 & $41.21 \%$ & 5131 & 1411 & $-72.5 \%$ \\
\hline
\end{tabular}

Table 6

Andalusian LUs. Analysis of Average CI changes per main natural land uses from 2005 to 2009.

\begin{tabular}{|c|c|c|c|c|c|c|c|}
\hline \multirow[t]{2}{*}{ LUs } & \multirow[b]{2}{*}{2005} & \multicolumn{3}{|l|}{ Avg $C I$} & \multicolumn{3}{|c|}{ Area (ha) } \\
\hline & & 2009 & $\Delta \mathrm{AvgCI}$ & 2005 & 2009 & $\Delta$ Area & \\
\hline \multirow[t]{4}{*}{ Las Lomas } & Land uses & & & & & & \\
\hline & Forests & 0.0090 & 0.0089 & $-1.16 \%$ & 75 & 75 & $0.0 \%$ \\
\hline & Shrub and/or herbaceous vegetation association & 0.0148 & 0.0145 & $-2.07 \%$ & 559 & 553 & $-1.1 \%$ \\
\hline & Open spaces with little or no vegetation & 0.0152 & 0.0148 & $-2.74 \%$ & 538 & 518 & $-3.7 \%$ \\
\hline \multirow[t]{4}{*}{ Litoral Occidental Onubense } & Land uses & & & & & & \\
\hline & Forests & 0.0368 & 0.0343 & $-6.62 \%$ & 12699 & 12583 & $-0.9 \%$ \\
\hline & Shrub and/or herbaceous vegetation association & 0.0215 & 0.0202 & $-6.06 \%$ & 14738 & 13854 & $-6.0 \%$ \\
\hline & Open spaces with little or no vegetation & 0.0139 & 0.0130 & $-6.66 \%$ & 3626 & 3424 & $-5.6 \%$ \\
\hline \multirow[t]{4}{*}{ Sierra Bermeja } & Land uses & & & & & & \\
\hline & Forests & 0.0445 & 0.0398 & $2.24 \%$ & 23252 & 23109 & $-0.6 \%$ \\
\hline & Shrub and/or herbaceous vegetation association & 0.0270 & 0.0253 & $-0.08 \%$ & 66154 & 65663 & $-0.7 \%$ \\
\hline & Open spaces with little or no vegetation & 0.0218 & 0.0202 & $3.03 \%$ & 4400 & 4388 & $-0.3 \%$ \\
\hline
\end{tabular}

Table 7

Average yearly variations of IFI, UFI, and CI for each LU selected.

\begin{tabular}{|c|c|c|c|c|c|c|}
\hline LU & $A Y V\lrcorner F I$ & & $A Y V_{-} U F$ & & $A Y V_{-} C I$ & \\
\hline Golfo dell'Asinara & $1.78 \%$ & Low & $4.91 \%$ & High & $-1.99 \%$ & Low \\
\hline Regione delle giare basaltiche & $0.20 \%$ & Low & $1.54 \%$ & Low & $1.62 \%$ & High \\
\hline Gennargentu and Mandrolisai & $4.95 \%$ & High & $0.00 \%$ & Low & $-2.90 \%$ & Low \\
\hline Las Lomas & $1.15 \%$ & Low & $2.21 \%$ & High & $0.48 \%$ & High \\
\hline Litoral Occidental Onubense & $2.27 \%$ & High & $0.00 \%$ & Low & $1.61 \%$ & High \\
\hline Sierra Bermeja & $1.44 \%$ & Low & $3.85 \%$ & High & $2.02 \%$ & High \\
\hline Mean & $1.96 \%$ & & $2.08 \%$ & & $0,14 \%$ & \\
\hline
\end{tabular}

Onubense, and it is concentrated where new linear infrastructures are constructed (red zones in Fig. 4 top and middle, Fig. 5 illustrates a detail in Litoral Occidental Onubense, where new infrastructures cause a high loss of LC). Table 6 shows a moderate gain in average $C I$ in forests and open spaces in LU Sierra Bermeja $\left(\Delta C I^{*}=2.24 \%\right.$ and $\Delta C I^{*}=3.03 \%$. The LU Las Lomas has the lowest LC values $(0.0090$, 0.0148 and 0.0152 ). The reason is that it is mainly an agricultural area with scattered natural landuses. However, the loss of LC between 2005 and 2009 has not been very pronounced in this LU.

\subsection{Relationship between fragmentation and connectivity}

As for the study of the relation between the LF and LC indices, we applied the method introduced in section 3.2. In Table 7, we report the AYV values of $I F I^{*}, U F I^{*}$, and $C I^{*}$. The pattern of qualitative values reflects what reported in section 4.2.

In Table 8, we report on the contingency tables and in Table 9 we present the results of the Fisher's exact test.

As the entire set of $p$-values (greater than 0.05) demonstrates, the Fisher's exact test reveals independency between the variables.
We precise that this result does not necessarily imply that LF and $\mathrm{CI}$ indices are never associated. Our results testify that there is not dependence between the indicators' values calculated on the set of the LUs considered in this specific study.

\subsection{Discussion}

In this paper we have demonstrated the effectiveness of $I F I^{*}$ and $U^{*}{ }^{*}$ in assessing the dynamics of LF caused by transport and mobility infrastructures and human settlements in two regions of Italy and Spain (as required by $\mathrm{RQ}_{1}$ and $\mathrm{RQ}_{3}$ ). The shortcomings of the IFI variability with respect to the extension of the LUs has been overcome by selecting LUs having approximately the same surface area (Bruschi et al., 2015; La Rovere et al., 2006; Romano and Tamburini, 2001). In the time periods considered, Golfo dell'Asinara and Litoral Occidental Onubense are the most fragmented LUs because of transport infrastructures. Golfo dell'Asinara shows the highest values for IFI and UFI in Sardinia. These are due to a high density of transport infrastructures, including railways, and urban settlements. The LU hosts an industrial development area of regional 


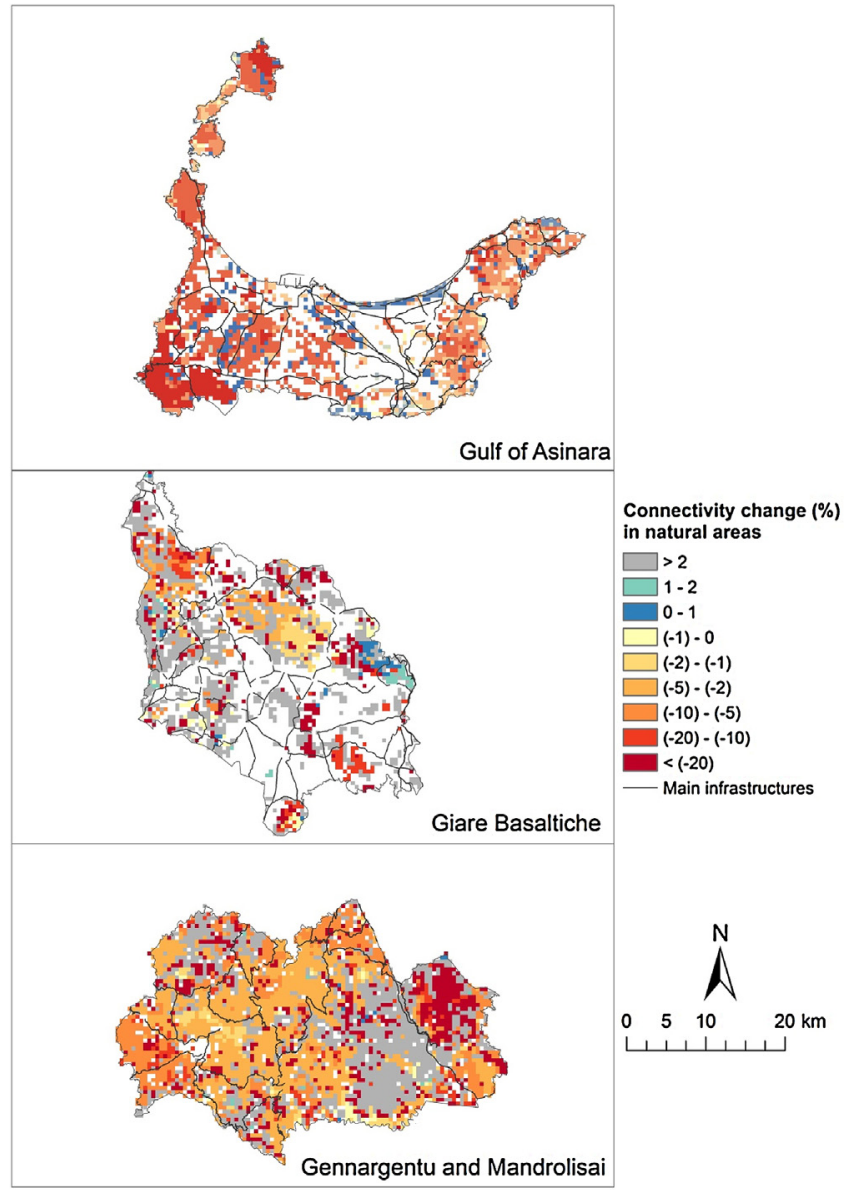

Fig. 3. Sardinian LUs. Analysis of CI changes in the time period 2003-2008.

interest in the coastal town of Porto Torres, which is also a very important harbour connecting Sardinia to Europe. Two centers, Stintino and Alghero, are attractive tourist destinations. In partic-

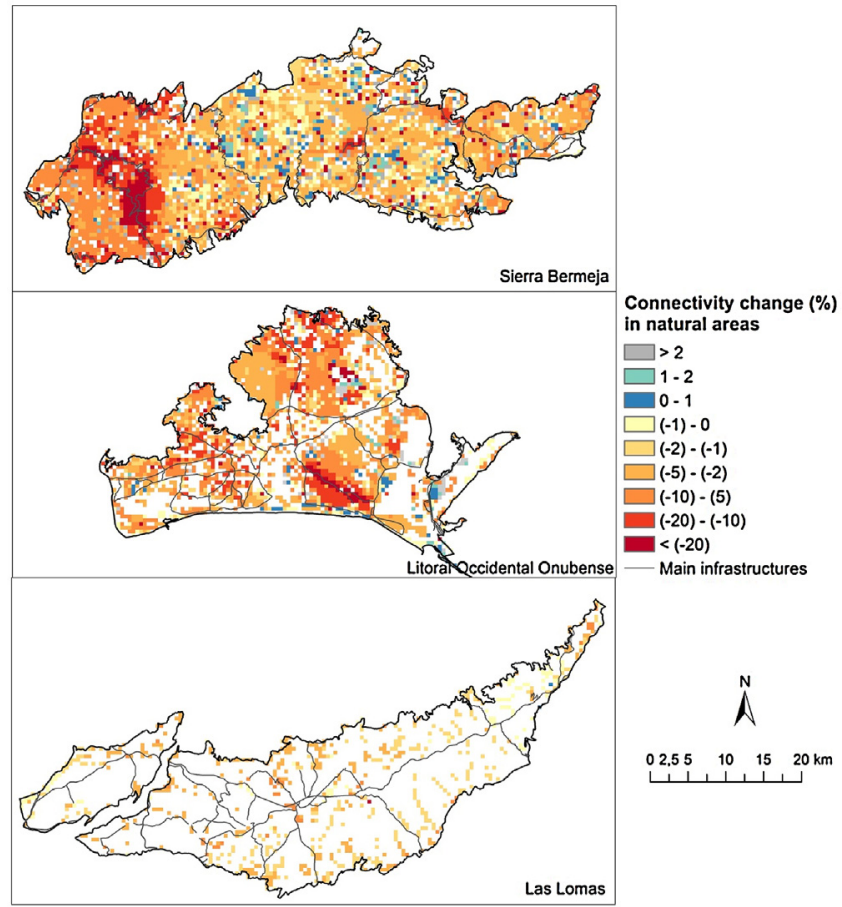

Fig. 4. LUs Las Lomas and Litoral Occidental Onubense. Analysis of CI changes from 2005 to 2009 and location of new roads.

ular, Alghero is an international touristic site connected with an airport which has been in the last decade the base of a low cost company. Although the LU Gennargentu-Mandrolisai has the lowest levels of fragmentation, it shows the highest IFI increase. However, the percentage change can be misleading and leads one to think at high levels of fragmentation, while the 2008 value (24.63\%) is due to a single fragment in addition to the original four fragments existing in 2003. The Spanish LUs of Las Lomas and Sierra Bermeja show a more regular UFI variation than the LU Litoral Occidental Onubense, where the $U F I^{*}$ has very high values and does not vary from 2005 to 2009.

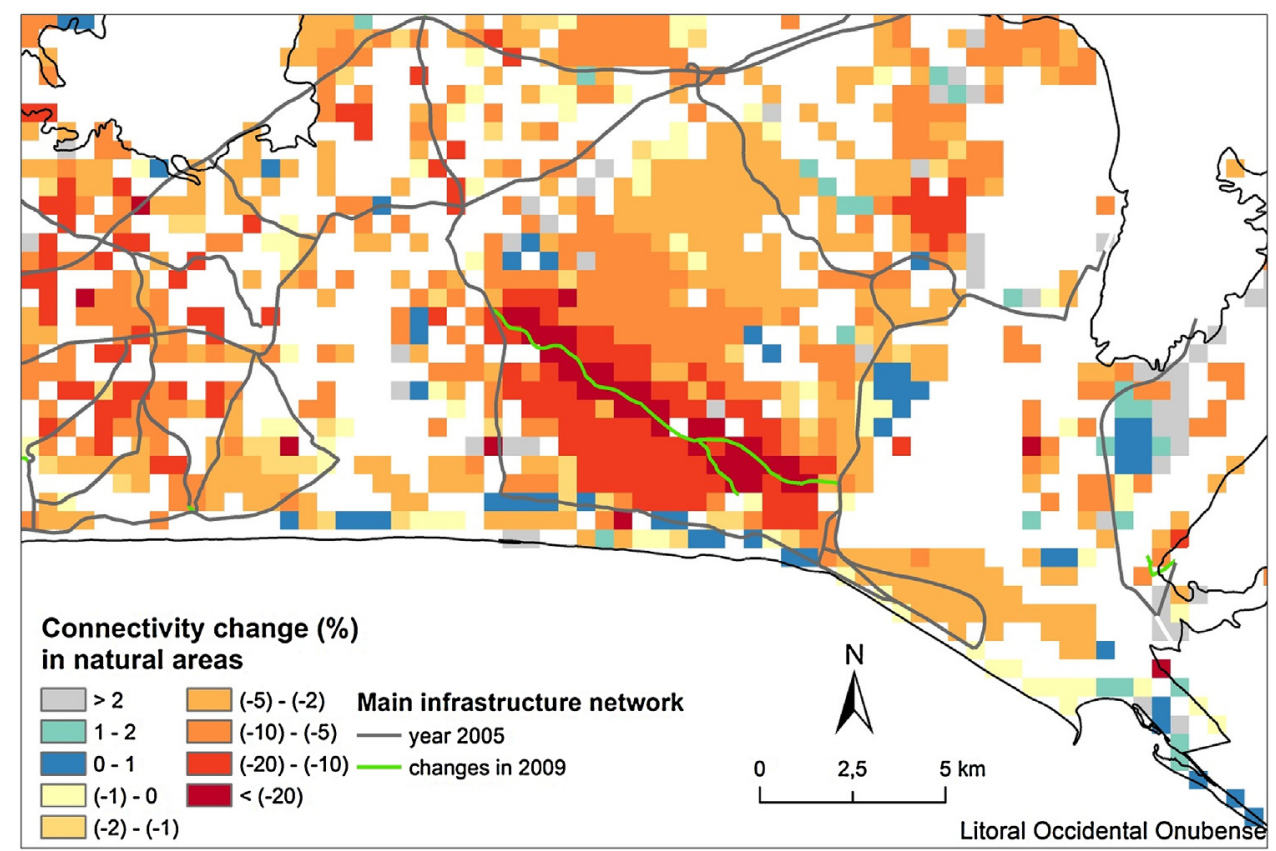

Fig. 5. Detail of the LU Litoral Occidental Onubense, where new infrastructures lead to a high loss of LC. 


\section{Table 8}

Contingency tables concerning the mutual variation of the three indices: on the top, AYV of IFI vS AYV of UFI; in the centre, AYV of IFI vs AYV of CI; on the bottom, AYV of UFI vs AYV of CI.

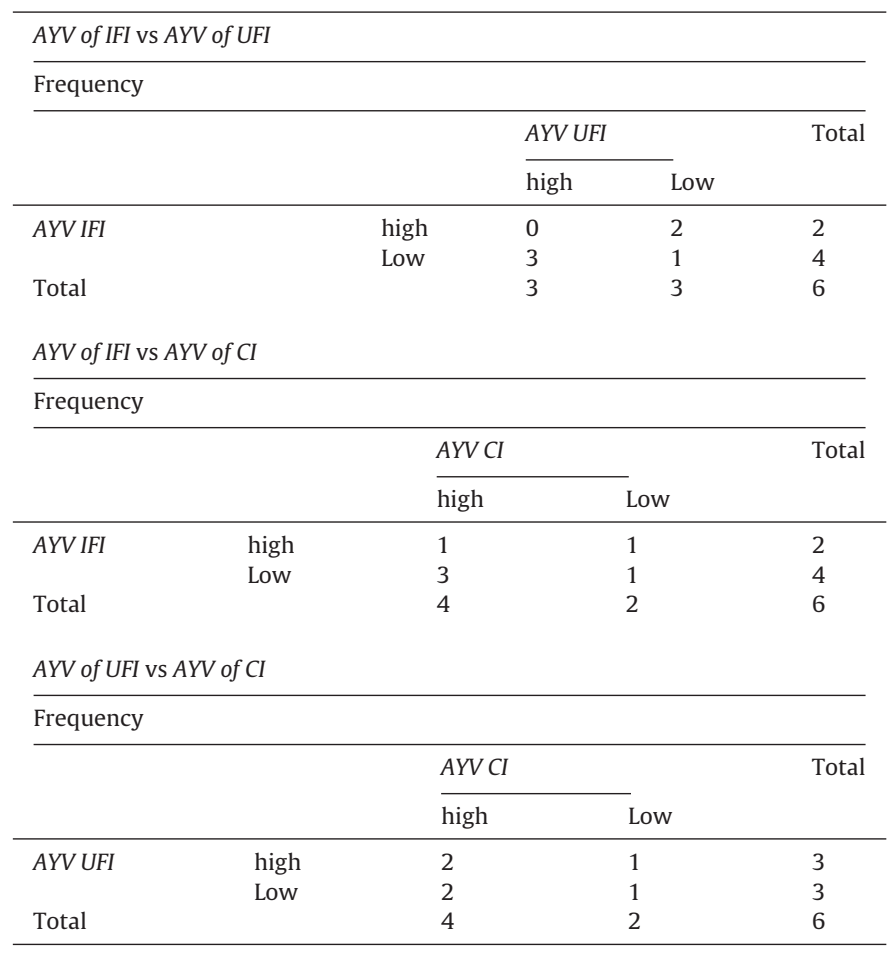

We have described the dynamics in LC of two Mediterranean regions belonging to Italy and Spain in two time periods, as we set out in the $\mathrm{RQ}_{1}$ and $\mathrm{RQ}_{3}$. $\mathrm{CI}^{*}$ has demonstrated to be an effective measure of LC for our objectives, in comparison with other indicators in the literature, which are valid measures of LC but cannot compare different landscapes or the same landscape in different time periods (Marulli and Mallarach, 2005). In general, average $\mathrm{CI}^{*}$ changes in Andalusian natural land uses are lower (absolute value) compared to $\mathrm{Cl}^{*}$ changes in Sardinia. Forests in Golfo dell'Asinara and open spaces with little or no vegetation in Regione delle giare basaltiche and Gennargentu and Mandrolisai show the highest absolute differences. These changes in $\mathrm{CI}^{*}$ are accompanied by high changes in the area of the natural land uses. According to the land use maps of Sardinian LUs, the area of the natural land uses has suffered significant changes, nevertheless, in Andalusia natural areas have been more stable (Tables 6 and 7). Our results show that area decreases are associated with average $\mathrm{CI}^{*}$ decreases except in the case of open spaces with little or no vegetation in Gennargentu and Mandrolisai, and forests and open spaces with little or no vegetation in Sierra Bermeja. In these cases, in spite of the loss of area, the new spatial configuration of pixels make the average $\mathrm{CI}^{*}$ of the remaining pixels increase due to the diminish of effective distances.

Regarding $R_{2}$, we have also studied the relationship between LF and LC. We found that results of $\mathrm{CI}^{*}$ complement LF indices but we did not arrive to any statistical evidence of a correlation between those indices. The Fischer's exact test does not allow to conclude that any dependence can be detected. This is clearly due to the values obtained with reference to the six LUs selected in this study and to the different scale of analysis. LF indices can be thought of as macro indicators based on variables assessed at a strategic scale over a wide area. By contrast, $\mathrm{CI}^{*}$ calculations are pixel based; they show results taking into account the area and the spatial distribution of habitats, transport infrastructures and artificial land uses in the landscape matrix.
Table 9

Fisher's exact test of the association between AYV of IFI, UFI, and CI.

\begin{tabular}{lll}
\hline & $A Y V_{-} U F I$ & $A Y V_{-} C I$ \\
\cline { 2 - 3 } & $\mathrm{p}$-value of the Fisher test & p-value of the Fisher test \\
\hline AYV_IFI & 0.4 & 1 \\
AYV_UFI & & 1 \\
\hline
\end{tabular}

\section{Conclusions}

With reference to $R Q_{1}$, in this article we have demonstrated the possibility to assess LF and LC due to urban and transport infrastructure expansion in space and time. In particular, we have applied a set of metrics to describe the dynamics of two Mediterranean regions belonging to Italy and Spain. We have calculated the indicators using spatial data and compared scenarios corresponding to different years. As for $\mathrm{RQ}_{2}$, intuition suggests that some relation may hold between fragmentation and connectivity measures: they give complementary information about landscape evolution. IFI and UFI make it possible to assess fragmentation in landscape units while $C I$ complements these metrics at the pixel level. Furthermore, IFI ${ }^{*}$ and $U F I^{*}$ values change substantially, when landscapes are affected by new artificial developments, while $\mathrm{Cl}^{*}$ takes also into account the pattern and variations of natural land uses. On the other hand, the application of the Fischer's exact test reports on the absence of any significant association between the indices. This does not mean that in general the indices are never correlated. But in our case the average yearly variation of the variables in the six LUs does not present correlation. With respect to $R Q_{3}$, the application of the method to the case studies enabled to find if the evolution of LF has been similar in Mediterranean areas. For example, the most fragmented LUs are Golfo dell'Asinara and Litoral Occidental Onubense. This is due to the coastal location of the areas, the high touristic and sometimes industrial pressure, and a connected demand of new transport infrastructures and settlements. We have found that the evolution of $\mathrm{Cl}^{*}$ is different in the regions studied. LC has been more stable in the Andalusian LUs than in the Sardinian ones in the time periods considered. This may be due to a different pace of political and operative drivers, which affect the intensity of land use changes.

While we have generally succeeded in developing on the RQs, this study still presents some limitations. First, we have considered a relatively small sample of cases. The number of LUs (six) is actually limited and can be expanded both in the same and in different Mediterranean or broadly European countries. In this way, a comparison of more countries would be possible. A higher number of cases would also lead to a higher statistical significance in the Fischer's exact test concerning the level of dependence between the various variables. Secondly, our study approaches LF and LF with an emphasis for analytical issues. By contrast, we are aware that landscape fragmentation and connectivity are the result of strategies and policies operationalized in historical and contemporary times through plans and actions. In this respect, a study of the sensitivity analysis is under way to clarify the economic and political drivers/implications of the unitary variation of LF and LF indices. In third place, LF and LC indicators selected still present some limitations. IFI $^{*}$ scales differently depending on the surface area of the LUs. This prevents the application of the measure to many LUs with significant differences in extension. Secondly, a finer computation of the index would require processing a much wider dataset on traffic flows in space and time. Finally, in the formulation adopted in this paper, IFI does not take into account the barrier effect a transport and mobility infrastructure exerts on specific wildlife species. We are tackling this issue in future works. On the other side, $U F I^{*}$ 's formulation adopted in this paper does not take into 
account the obstruction generated by different types of human settlement. Although $C I^{*}$ has been demonstrated to be a good measure of LC and a complement for LF measures, it also has shortcomings. $C I^{*}$ is unable to identify stepping stones, it assumes simplifications in the landscape matrix, and considers only movements between natural land uses of the same type. These shortcomings are solved by other models using probability of paths (see Saura and PascualHortal, 2007; Gurrutxaga et al., 2011 and Loro et al., 2015), but they quantify LC in the entire landscape and do not take into account the types of infrastructures.

\section{Acknowledgement}

The authors thank the anonymous reviewers for their very helpful and insightful comments.

\section{References}

Astiaso Garcia, D., Bruschi, D., Cinquepalmi, F., Cumo, F., 2013. An estimation of urban fragmentation of natural habitats: case studies of the 24 Italian national parks. Chem. Eng. Trans. 32, 49-54.

Battisti, C., Romano, B., 2007. Frammentazione e connettività. Dall'analisi ecologica alla pianificazione ambientale. CittàStudi, Torino.

Battisti, C., Conigliaro, M., Poeta, G., Teofili, C., 2013. Biodiversità, disturbi, minacce. Dall'ecologia di base alla gestione e conservazione degli ecosistemi. Editrice Universitaria Udinese srl, Udine.

Battisti, C., 2004. Frammentazione ambientale, connettività, reti ecologiche. Un contributo teorico e metodologico con particolare riferimento alla fauna selvatica. Provincia di Roma, Assessorato alle politiche ambientali, Agricoltura e Protezione civile, Roma.

Biondi, M., Corridore, G., Romano, B., Tamburini, G., Tetè, P., 2003. Evaluation and Planning Control of the Ecosystem Fragmentation due to Urban Development. In: 50th Conference of the European Regional Science Association (ERSA), Jyväskylä, Finland, August 27-30.

Blondel, J., Aronson, J., Bodiou, J.Y., Boeuf, G., 2010. The Mediterranean Region: Biological Diversity in Space and Time. Oxford University Press Inc., New York.

Bruschi, D., Astiaso Garcia, D., Gugliermetti, F., Cumo, F., 2015. Characterizing the fragmentation level of Italian's National Parks due to transportation infrastructures. Transp. Res. D-Tr. E. 36, 18-28.

Butler, B.J., Swenson, J.J., Alig, R.J., 2004. Forest fragmentation in the Pacific Northwest: quantification and correlations. For. Ecol. Manag. 189 (1-3), 363-373.

Collinge, S.K., 1996. Ecological consequences of habitat fragmentation: implications for landscape architecture and planning. Landsc. Urban Plan. 36 (1), 59-77.

Council of Europe, 2000. European Landscape Convention. Council of Europe, Firenze.

Cuttelod, A., García, N., Abdul Malak, D., Temple, H., Katariya, V., 2008. The Mediterranean: a biodiversity hotspot under threat. In: Vié, J.-C., Hilton-Taylor, C., Stuart, S.N. (Eds.), The 2008 Review of The IUCN Red List of Threatened Species. IUCN Gland, Switzerland.

De Montis, A., Caschili, S., Mulas, M., Modica, G., Ganciu, A., Bardi, A., Ledda, A., Dessena, L., Laudari, L., Fichera, C.R., 2016. Urban-rural ecological networks for landscape planning. Land Use Policy 50, 312-327, http://dx.doi.org/10.1016/j. landusepol.2015.10.004.

De Montis, A., 2014. Impacts of the European landscape convention on national planning systems: a comparative investigation of six case studies. Landsc. Urban Plan. 124, 53-65.

De Montis, A., 2016. Measuring the performance of planning: the conformance of Italian landscape planning practices with the European Landscape Convention. Eur. Plan. Stud. 24, 1727-1745.

Dijkstra, E.W., 1959. A note on two problems in connexion [sic] with graphs. Numeriske Mathematik 1, 269-271.

EEA, 2011. Landscape Fragmentation in Europe, Joint EEA-FOEN Report. European Environment Agency, Copenhagen (Accessed February 28, 2016) http://www. eea.europa.eu/publications/landscape-fragmentation-in-europe.

Fabietti, V., Gori, M., Guccione, M., Musacchio, M.C., Nazzini, L., Rago, G., 2011. Frammentazione del territorio da infrastrutture lineari. Indirizzi e buone pratiche per la prevenzione e la mitigazione degli impatti. ISPRA - Istituto Superiore per la Protezione e la Ricerca Ambientale, Roma.

Foley, J.A., DeFries, R., Asner, G.P., Barford, C., Bonan, G., Carpenter, S.R., Chapin, F.S. Coe, M.T., Daily, G.C., Gibbs, H.K., Helkowski, J.H., Holloway, T., Howard, E.A. Kucharik, C.J., Monfreda, C., Patz, J.A., Prentice, I.C., Ramankutty, N., Snyder, P.K., 2005. Global consequences of land use. Science 309 (5734), 570-574.

Foley, J.A., Ramankutty, N., Brauman, K.A., Cassidy, E.S., Gerber, J.S., Johnston, M., Mueller, N.D., O’Connell, C., Ray, D.K., West, P.C., Balzer, C., Bennett, E.M. Carpenter, S.R., Hill, J., Monfreda, C., Polasky, S., Rockström, J., Sheehan, J., Siebert, S., Tilman, D., Zaks, D.P.M., 2011. Solutions for a cultivated planet. Nature 478 (7369), 337-342.
Forman, R.T.T., Sperling, D., Bissonette, J.A., Clevenger, A.P., Cutshall, C.D., Dale, V.H., Fahrig, L., France, R.L., Goldman, C.R., Heanue, K., Jones, J., Swanson, F., Turrentine, T., Winter, T.C., 2003. Road ecology. In: Science and Solutions. Island Press, Washington.

Gibson, L., Lynam, A.J., Bradshaw, C.J.A., He, F., Bickford, D.P., Woodruff, D.S., Bumrungsri, S., Laurance, W.F., 2013. Near-complete extinction of native small mammal fauna 25 years after forest fragmentation. Science 341 (6153), $1508-1510$

Guccione, M., Gori, M., Bajo, N., 2008. Tutela della connettività ecologica del territorio e infrastrutture lineari. ISPRA - Istituto Superiore per la Protezione e la Ricerca Ambientale, Roma.

Gurrutxaga, M., Rubio, L., Saura, S., 2011. Key connectors in protected forest area networks and the impact of highways: a transnational case study from the Cantabrian Range to the Western Alps (SW Europe). Landsc. Urban Plan. 101, 310-320.

Harrisson, K.A., Pavlova, A., Amos, J.N., Takeuchi, N., Lill, A., Radford, J.Q., Sunnucks, P., 2012. Fine-scale effects of habitat loss and fragmentation despite large-scale gene flow for some regionally declining woodland bird species. Landsc. Ecol. 27 (6), 813-827.

Henle, K., Davies, K.F., Kleyer, M., Margules, C., Settele, J., 2004. Predictors of species sensitivity to fragmentation. Biodivers. Conserv. 13, 207-251.

IDEA, 2016. Infraestructura de datos espaciales de Andalucía (bureau of spatial data of Andalusia) (Accessed June 16, 2016) http://www.ideandalucia.es/ portal/web/ideandalucia/.

Igondova, E., Pavlickova, K., Majzlan, O., 2016. The ecological impact assessment of a proposed road development (the Slovak approach). Environ. Impact Assess. Rev. 59, 43-54.

Italian regulation, 2004. Decreto legislativo del 24 gennaio 2004 No. 42 Codice dei beni culturali e del paesaggio (Legislative decree approved on January, 24th 2004 No. 42 Code about cultural heritage and landscape). Gazzetta Ufficiale 45 (2004) (in Italian).

Jaarsma, C.F., Willems, G.P.A., 2002. Reducing habitat fragmentation by minor rural roads through traffic calming. Landsc. Urban Plan. 58 (2-4), 125-135, http:// dx.doi.org/10.1016/S0169-2046(01)00215-8.

Jaarsma, C.F., 2004. Ecological 'black spots' within the ecological network: an improved design for rural road network amelioration. In: Jongman, R.H.G., Pungetti, G. (Eds.), Ecological Networks and Greenways: Concept, Design Implementation. Cambridge University Press, Cambridge, pp. 171-187.

Jaeger, J.A.G., 2000. Landscape division, splitting index, and effective mesh size: new measures of landscape fragmentation. Landsc. Ecol. 15 (2), 115-130.

Jongman, R.H.G., 2004. The context and concept of ecological networks. In: Jongman, R.H.G., Pungetti, G. (Eds.), Ecological Networks and Greenways: Concept, Design Implementation. Cambridge University Press, Cambridge, pp. 7-33.

Junta de Andalucía, 2003. Mapa de Paisajes de Andalucía (Map of Andalusian Landscapes) (Accessed June 16, 2016) http://www.juntadeandalucia.es/ medioambiente/site/rediam/menuitem. 04dc44281e5d53cf8ca78ca731525ea0/?vgnextoid=44f3d3b35 c39c410VgnVCM2000000624e50aRCRD\&vgnextchannel =2f5d19117570f210VgnVCM1000001325e50aRCRD\&vgnextfmt =rediam\&lr=lang_es.

Junta de Andalucía, 2006. Plan de Ordenación del Territorio de Andalucía. Consejería de Obras públicas y transportes. Sevilla.

Junta de Andalucia, 2016. Sistema de Información sobre Ocupación del Suelo de España en Andalucía(Land use Information System of Spain) (SIOSE) (Accessed June, 16 2016) http://www.juntadeandalucia.es/medioambiente/site/ portalweb/menuitem.7e1cf46ddf59bb227a9ebe205510e1ca/ ?vgnextoid=fbec73f552215310VgnVCM2000000624e50aRCRD\&vgnext channel=637c545f021f4310VgnVCM1000001325e50aRCRD.

Kettunen, M., Terry, A., Tucker, G., Jones, A., 2007. Guidance on the Maintenance of Landscape Features of Major Importance for Wild Flora and Fauna - Guidance on the Implementation of Article 3 of the Birds Directive (79/409/EEC) and Article 10 of the Habitats Directive (92/43/EEC). Institute for European Environmental Policy (IEEP), Brussels, pp. 114 (Annexes).

La Rovere, M., Battisti, C., Romano, B., 2006. Integrazione dei parametri eco-biogeografici negli strumenti di pianificazione territoriale. In: XXVII Conferenza Italiana di Scienze Regionali, Pisa, October 12-14.

Lega, P., 2004. La frammentazione infrastrutturale del territorio nella provincia di Piacenza Internal Report n. 05/04 (Accessed April 20 2016) http://www2. provincia.pc.it/cartografico/cartografia/img/elab_tem/04_05.pdf.

Li, M., Huang, C., Zhu, Z., Shi, H., Lu, H., Peng, S., 2009. Assessing rates of forest change and fragmentation in Alabama, USA, using the vegetation change tracker model. For. Ecol. Manag. 257 (6), 1480-1488.

Li, M., Mao, L., Zhou, C., Vogelmann, J.E., Zhu, Z., 2010. Comparing forest fragmentation and its drivers in China and the USA with Globcover. J. Environ. Manag. 91 (12), 2572-2580.

Lindenmayer, D.B., Franklin, J.F., 2002. Conserving Forest Biodiversity: a Comprehensive Multiscaled Approach. Island Press, Washington, DC.

Loro, M., Ortega, E., Arce, R., Geneletti, D., 2015. Ecological connectivity analysis to reduce the barrier effect of roads: an innovative graph-theory approach to define wildlife corridors with multiple paths and without bottlenecks. Land. Urban Plan. 139, 149-162.

Mancebo Quintana, S., Martín Ramos, B., Casermeiro Martínez, M.A., Otero Pastor, I., 2010. A model for assessing habitat fragmentation caused by new infrastructures in extensive territories - evaluation of the impact of the 
Spanish strategic infrastructure and transport plan. J. Environ. Manag. 91 (5), 1087-1096

Martín, B., Ortega, E., Otero, I., Arce, R., 2016. Landscape character assessment with GIS using map-based indicators and photographs in the relationship between landscape and roads. J. Environ. Manag. 180, 324-334.

Marulli, J., Mallarach, J.M., 2005. A GIS methodology for assessing ecological connectivity: application to the Barcelona Metropolitan Area. Landsc. Urban Plan. 71, 243-262.

McGarigal, K., Marks, B.J., 1995. FRAGSTATS: Spatial Pattern Analysis Program for Quantifying Landscape Structure. United States Department of Agriculture, Forest Service, Pacific Northwest Research Station, Portland.

Melis, G., Puddu, G., 2008. Gli algoritmi di cost-distance come strumento di supporto per la pianificazione alla scala provinciale delle reti ecologiche. In: XII Conferenza Nazionale ASITA, L'Aquila, October 21-24.

Neri, M., Menconi, M.E., Vizzari, M., Mennella, V.G.G., 2010. Propuesta de una nueva metodología para la ubicación de infraestructuras viarias ambientalmente sostenibles. Aplicación en el tramo viario de la pedemontana Fabriano-Muccia. Informes de la Construcción 62 (517), 101-112.

Ortega, E., Martín, B., Gonzalez, E., Moreno, E., 2016. A contribution for the evaluation of the territorial impact of transport infrastructures in the early stages of the EIA: application to the Huelva (Spain)-Faro (Portugal) rail link. J. Environ. Plan. Manag. 59 (2), 302-319.

RAS, 2006. Regional Landscape Plan (RLP) (Accessed February 1 2016) http://www. sardegnageoportale.it/index.php?xsl=1598\&s=292285\&v=2\&c=8771\&t=1.

RAS, 2016a. Carta dell'uso del suolo [Regional Land Cover Map -RLCM]. http:// www.sardegnageoportale.it/argomenti/cartedelsuolo.html.

RAS, 2016b. Geoportale. Raccolte cartografiche. Geografia della Sardegna. Regione Autonoma della Sardegna (Accessed April 16, 2016) http://www. sardegnageoportale.it/index.php?xsl=1594\&s=40\&v=9\&c=8831\&na=1\&n=100.

Romano, B., Tamburini, G., 2001. Gli indicatori di frammentazione e di interferenza ambientale nella pianificazione urbanistica. In: XXII Conferenza Italiana di Scienze Regionali, Venezia, October 10-12.

Romano, B., Zullo, F., 2013. Valutazione della pressione insediativa: indicatori e sperimentazione di soglie. In: Battisti, C., Conigliaro, M., Poeta, G., Teofili, C. (Eds.), Biodiversità, disturbi, minacce. Editrice Universitaria Udinese, Udine, pp. 170-177.
Romano, B., 2002. Evaluation of urban fragmentation in the ecosystems. In: International Conference on Mountain Environment and Development (ICMED), CHENGDU, Sichuan, China, October 15-19.

Saunders, D.A., Hobbs, R.J., Margules, C.R., 1991. Biological consequences of ecosystem fragmentation: a review. Conserv. Biol. 5 (1), 18-32, http://dx.doi org/10.1111/j.1523-1739.1991.tb00384.x.

Saura, S., Pascual-Hortal, L., 2007. A new habitat availability index to integrate connectivity in landscape conservation planning: comparison with existing indices and application to a case study. Landsc. Urban Plan. 83, 91-103.

Scolozzi, R., Geneletti, D., 2012. Assessing habitat connectivity for land-use planning: a method integrating landscape graphs and Delphi survey. J. Environ. Plan Manag. 55 (6), 813-830.

Serrano, M., Sanz, L., Puig, J., Pons, J., 2002. Landscape fragmentation caused by the transport network in Navarra (Spain). Two-scale analysis and landscape integration assessment. Landsc. Urban Plan. 58 (2-4), 113-123, http://dx.doi. org/10.1016/S0169-2046(01)00214-6.

Smith, D.J., 2004. Impacts of roads on ecological networks and integration of conservation and transportation planning: florida as a case study. In: Jongman, R.H.G., Pungetti, G. (Eds.), Ecological Networks and Greenways: Concept, Design Implementation. Cambridge University Press, Cambridge, pp. 73-93.

Spellerberg, I., 1998. Ecological effects of roads and traffic: a literature review. Glob. Ecol. Biogeogr. 7, 317-333.

Taylor, P.D., Fahrig, L., Henein, K., Merriam, G., 1993. Connectivity is a vital element of landscape structure. Oikos 68 (3), 571-573.

Trocmé, M., Cahill, S., de Vries, J.G., Farrall, H., Folkeson, L.G., Hichks, C., Peymen, J. (Eds.), 2003. COST 341 - Habitat Fragmentation due to Transportation Infrastructure: The European Review. Office for official publications of the European Communities, Luxembourg.

Wilcove, D.S., McLellan, C.H., Dobson, A.P., Soulé, M.E., 1986. Habitat fragmentation in the temperate zone. In: Conservation Biology: The Science of Scarcity and Diversity. Sinauer Associates Inc., Sunderland, Massachussets, pp. 237-256.

Zanon, B., Geneletti, D., Franceschini, A., 2007. L'integrazione dei valori antropici, visuali ed ambientali nella zonizzazione dei parchi naturali. Agribus. Paesaggio Ambiente 10 (2), 126-137. 